\title{
Internationalization as Investment for Higher Education Institutions: Introducing a Framework to Enhance Investment in Internalization practices
}

\author{
Jamshed Khalid a*, Anees Janee Ali a, Md. Shamimul Islam a, b, Muhammad Khaleel a, Qi Fang Shu a \\ a School of Management, University Sains Malaysia. \\ B Faculty of Business, ASA University Bangladesh \\ ${ }^{*}$ Corresponding author's email address: Jamshed.jt@gmail.com
}

\section{A R T I C L E I N F O}

Received: 06-02-2017

Accepted: 07-02-2017

Available online: 16-02-2017

Keywords:

International students; Internationalization;

Investment;

Globalization;

Higher education.

JEL Classification: I23,I22, H52, H75

\begin{abstract}
A B S T R A C T
Prior research has reflected various conceptualizations of internationalization in higher education and offered various perspectives on its activities and practices which in result have produced different pragmatic outcomes. In the 21st century, higher education institutions (HEIs) are progressively mobile as well as globally competitive and in response practices and strategies adopted by HEIs needed to reshape in global context. The present study is the qualitative study based on prior literature and reveals a comprehensive review about the factors influencing internationalization practices. The present study contributed to the existing literature by illustrating a conceptual framework to enhance the investment in internationalization activities by HEIs. It is argued that effectiveness of internationalization depend on the rise of internationalization at home activities, student/staff exchange programs, expanding ventures and institutional networks and alliances. The study is prominently significant for HEIs as it is offering practical suggestions to speed up internationalization process.
\end{abstract}

This is an open access article under the terms of the Creative Commons Attribution License 4.0, which allows use, distribution and reproduction in any medium, provided the original work is properly cited.

DOI: http://dx.doi.org/10.18533/rss.v2i2.87

ISSN 2378-8569(Print), ISSN 2378-8550(Online)

\section{Introduction}

Investment in knowledge and competence is the sustainable core of national and institutional success strategy. In the $21^{\text {st }}$ century, we are working in technology-driven knowledge-based global societies where education and knowledge are perceived as commodity and industry (Calzolari, 2010; Petetr, 2002). As Daniels (2013) points out, drive for internationalization in higher education is not without its challenges and potential for conflict among a wide range of local and global stakeholders with divergent motivations and perspectives. Higher education institutes (HEIs) have assertive reasons to invest in internationalization activities as it can lead to attain higher earnings, goodwill and competitive advantages in global market (Minola, T., Donina, D., \& Meoli, M., 2016).

Despite there is profuse attention in the internationalization higher education literature (Altbach and Knight 2007; de Wit 2015; Knight 2014), there is still marginal focus on considering internationalization as investment. HEIs from developing and under developing countries are not actively participating to develop a global knowledge economy and due to this they are not able to attract international students and less competitive. Current study is an effort to fill that gap by highlighting the significance of investing in internationalization activities by indicating its dynamic outputs. This paradox is gaining fame (Hudson, R. 2016; Cattaneo, M., Meoli, M., \& Paleari, S. 2016; Kemp, N. 2016) because of its practical significance and diffusion. Current study proposed a framework to enhance the investment in internationalization activities to maximize institutional earning, expand goodwill and 
reputation and attain competitive advantage. The study, finally, discuss the practices and policies for HEIs to speed up the internationalization process.

Prior research specifies motivations for internationalization as economic competitiveness, knowledge and language attainment, environmental interdependence, mobility of students and staff, curriculum enhancement and research collaboration (Warner 1992; Altbach, 2007; Scott 1992; Knight \& De Wit 1995). HEIs are taking initiatives such as branch campuses regionally and internationally, student/staff exchange programs, internationally focused study programs, cross-border research cooperation and spreading the strategic alliances and institutional networks globally (Mohsin, A., \& Zaman, K. 2014; Knight, J. 2006).

Internationalization, in the $21^{\text {st }}$ century, has been considered as a mantra in higher education. The knowledge economy is a global network and universities across the world are encouraged to take part to acquire the benefits of global interconnectedness. Therefore, global capital impressively invested in knowledge industries worldwide, which include globalization of HEIs and advanced training programs to get the outcomes through internationalization (Altbach \& Knight, 2007).

The rest of the paper is organized as follows: in section 2, prior literature has been discussed, then, outcomes from internationalization are explained in section 3. Conceptual framework to enhance investment in internationalization is presented in section 4 . At the end, section 5 comprised of discussion and policy implications, conclusion and suggestions for future research.

\section{Literature review}

\subsection{Internationalization}

For over 20 years, the definition of internationalization has been the subject of much discourse. Internationalization is not a new term. One widely used definition for internationalization given by Jane knight is "The process of integrating an international or intercultural dimension into the teaching, research, and service functions of the institution." The popularity of the term 'internationalization' in the education sector groomed since the early 1980s. In ara of 1990s, the debate on using the term 'international education' centered on differentiating it from comparative education, global education, and multicultural education. Wilson (2013, p.30) argues that "internationalization is an increasingly important strategic priority not only for institutions but also for governments, which are increasingly aware of the importance of universities in supporting national and regional competitiveness."

In the first decade of the 21st century, a new set of related terms is emerging that includes transnational education, borderless education, and cross-border education. The international dimension relates to all aspects of education and the role that it plays in society. Jane Knight (2003) updated the definition of internationalization as "Internationalization at the national, sector, and institutional levels are defined as the process of integrating an international, intercultural, or global dimension into the purpose, functions or delivery of postsecondary education." It demonstrates internationalization is a continuing and long-term struggle. Knight (2003), emphasis on three terms International, intercultural, and global dimension to describe the relationships, culture and diversity of culture among nations and institutions.

\subsection{Rationales and significnce of internationalization}

To internationalize the higher education, the rationales which have been classified in the literature are academic, economic, political and social (Knight, 2004; Stier, 2004). Academic motives for internationalization are based on satisfying the need of institution's educational mission and strategies, to remain academically relevant in an interconnected global world and to attract the best students and faculty worldwide. Similarly, economic motives of internationalization are to earn more revenue, to reduce operating risks/threats and to get resources for the activities on the home campus (Jane Knight, 2004; P.10 \& 11). Political and social motives also play a significant role in the internationalization of the educational institutions to achieve healthy survival of national identities, cultural diversity and balance homogenizing effect of globalization and emergence of the knowledge society and knowledge-based organizations for innovations in education and research (Hawawini, 2011).

Internationalization of higher education institutions (HEIs) are the topic of various reports, books, and publications (Wildavsky, 2010; AACSB, 2011). Internationalization is a broadly popular thought in the literature and describes as business development by expanding strategy, structure, and resources in the international market. Because of the broadening and speeding up of worldwide interconnectedness, HEIs have become more global and internationalized. 
Internationalization is a driving motive for change and innovation in higher education. It is a transformation process to enhance the quality of teaching, learning and to achieve the desired competencies. Internationalization of higher education is an ongoing course of action, and the efforts to internationalize are endless. The internationalization concept of higher education has itself become globalized (Elspeth Jones and Hans de Wit, 2014). It is integral to the strategic planning of the universities in the global market. For Policymakers, it has significant importance as it affects the economic performance by the cross-border flow of knowledge, student and staff exchange activity (OECD, 2004; NAFSA, 2010). Recent literature has considered different conceptualizations of internationalization of higher education and offered diverse perspectives. One study conducted by Ghulam Akhmat, Khalid Zaman, Tan Shukui and Tauseef Ahmed (2013) shows that there is a dynamic relationship between educational indicators and growth factors. Thus, there is a rapid need for universities around the globe to internationalize their campuses to sustain and energies higher education sector.

\subsection{Internationalization of HEIs as investment}

Internationalization of HEIs is an investment for the future and involves a long-term commitment to students, staff, and other stakeholders globally. Education is becoming an internationally traded commodity (Altbach, 2002). It is increasingly seen as a commodity to be purchased by a consumer to build a "skill set" to be used in the marketplace or a product to be bought and sold by multinational corporations, that is, academic institutions that have transform themselves into businesses entities, and other providers.

According to the United Nations Educational, Scientific and Cultural Organization (2014), the number of international students can rise to 8 million by 2025. Malaysia, under the Ministry of Higher Education, plans to have $250 \mathrm{k}$ international students by 2025 . Malaysia at the high end of developing economy is now already on the world map as a provider of international higher education. It has $2 \%$ of the potential world market compared to US 21.2\%, UK 12\%, France 9\%, Germany8.4\%, and Japan 4.7\% (Mohammad, 2011).

Previously, the phenomenon of international student mobility and cross-border education was considered to increase the mutual understanding and global cooperation among nations. However, in current scenario, maximizing revenue is the approach which worked as a motivation for growing competition between institutions to establish themselves in global knowledge market by attracting maximum consumer. For instance, in US Internationalization of higher education is an opportunity to upsurge revenue in globalized economy. Altbach \& Knight (2006) disclose that US economy is getting more than $\$ 12$ billion annually due to the international students approached to study in US.

Moreover, economy of the UK is gaining $£ 5$ billion per annum because of the mobility of international students (OECD, 2004). The recent statistics point out that international students, in the year of 2014, contributed almost $\$ 27$ billion dollar to the economy of US which shows $12 \%$ increment as $\$ 24$ billion in 2013 (Ortiz, Chang, \& Fang, 2015). International students in Australia, produce some 15 per cent of the whole income of HE system, while in $\mathrm{UK}$, contribution is almost 10 per cent of total income for the national universities. International education is the third largest export of Australia contributing US\$12 billion to the Australian economy (Adams, Banks, \& Olsen, 2011, p. 114). Furthermore, New Zealand also heavily depend on international students to assist its national HE system (Douglass \& Edelstein, 2010). According to De Wit (2010), in New Zealand, international education generates more earnings than export of wine; in Canada, more than lumber and coal; and in the UK, more than automotive or financial services. Therefore, students are the largest source of income for international education industry (Altbach \& Knight, 2006).

General Agreement on Trade in Services (GATS) treats education as commodity or service that traded cross border commercially. Now, the competition between the countries is to attract maximum number of international students, establish overseas branch campuses and develop international alliances and networks. (Knight, 2014).

In the current study, internationalization practices for HEIs discussed in four dimensions; internationalization at home (IaH), international students and faculty, expanding ventures and strategic alliances and institutional networks.

\subsection{Internationalization at home (IaH)}

The term internationalization is related to international mobility of student and staff, curriculum development and research collaboration internationally, recruitment of international students, international alliances or partnership, and other practices that which contains cross-border movements. Recently, internationalization at home (IaH) rapidly becomes a major concern for many universities, and it assists to enhance the quality of advance learning for all students domestically and internationally. Wächter (2003) defines internationalization 
at home as "Any internationally related activity except outbound student and staff mobility". IaH emphases on the formation of international and intercultural competencies at university campus at university's home institution (Knight, 2008).

Development of curriculum and home-internalization programs, faculty training and collaboration with local cultural/ethnic groups are some activities for implementation of IaH. Leask (2009) suggests that "the development of intercultural competencies in students is a key outcome of an internationalized curriculum, which requires a campus environment and culture that motivates and rewards interaction between international and home students in and out of the classroom" (205).

Beelen and Jones redefine the term IaH in 2015 as; "Internationalization at home is the purposeful integration of international and intercultural dimensions into the formal and informal curriculum for all students, within domestic learning environments. In the Netherlands, $76 \%$ of universities have already included internationalization at home curricula in their educational policies (Nuffic, 2014). As per European University Association survey (2015), 64\% of European higher education institutions are also practicing the IaH.

\section{$2.5 \quad$ International students and international faculty}

Over the last decade, the literature on mobility of international students has enlarged remarkably (Gürüz 2008; Solimano 2008; Williams and Balaz 2008). The demand for international students and multi-cultural academic faculty are the vital components of internationalization. International students are assets to HEIs as they increase the university value and recognition globally. Some previous studies have revealed a substantial link between student mobility and potential migration. One the major reason for student mobility is to obtain postgraduate employment in the host countries (Suter and Jandl 2006; Rosenzweig 2008).

According to UNESCO Institute for Statistics (2014), 4.1 million students went abroad to study in 2013, which represent $1.8 \%$ of all tertiary enrolments or 2 in 100 students globally. The report also describes that number of students in Central Asia has steady rise as it grew from 67,300 in 2003 to 165,542 in 2013, and the outbound mobility ratio more than doubling from $3.5 \%$ to $7.6 \%$.

The United States is at the top as the host country for the international student as it hosted $19 \%$ of total mobile students. The top ten destinations for international students indicated below in Table 1;

Table 1: International students' top ten destinations

\begin{tabular}{llr}
\hline Top ten destination countries & & $\begin{array}{r}\text { Percentage of total mobile } \\
\text { students }\end{array}$ \\
\hline 1 & United States & $19 \%$ \\
2 & United Kingdom & $10 \%$ \\
3 & Australia & $6 \%$ \\
4 & France & $6 \%$ \\
5 & Germany & $5 \%$ \\
6 & Russian Federation & $3 \%$ \\
7 & Japan & $3 \%$ \\
8 & Canada & $3 \%$ \\
9 & China & $2 \%$ \\
10 & Italy & $2 \%$ \\
\hline
\end{tabular}

Source: Self-elaboration from http://www.uis.unesco.org/

The mobility of students without the mobility of academic staff causes complications in the process to internationalization for HEIs (NAFSA, 2011). Recruiting permanent and visiting international staff members helpout in connecting teachers and students in global perspectives. Internationalisation strategies in most of the HEIs include a statement regarding the 'encouragement' of international staff mobility (Harris 2008; Killick 2007).

International professional academics, either tenure track or visitors, potentially contribute to institution and community. Institution's leadership and policy makers also play a significant role in ensuring that an aptitude for international perspectives must be an essential part of any recruitment process. Universities may attract international faculty by creating an environment where international efforts are emphasized and where teachers feel supported to pursue international research agendas. Visiting faculty also has a significant role in an institution's progress. 


\subsection{Expanding venture}

Ventures mean a business enterprise or speculation in which something is risked in the hope of profit; a commercial or other speculation. The universities are trying to create new resources for new or expanded ventures in education and research (Beelen and De Wit, 2012). Student mobility in higher education through studying abroad will be gradually enhanced by 'cross-border' education, defined as 'the educational service going to the students across national borders, instead of the student going to the service overseas'. Cross-border education often takes place in the form of higher education campuses located abroad or in the form of distance learning. Australia's Monash University have campuses in Malaysia that attract both local and international students (Ball, 2012). The same with the Heriot-Watt University from the UK that has a sub-campus in Putrajaya, Malaysia (Healey, 2015).

\subsection{Strategic alliances and institutional networks}

The strategic alliance is a setup where two companies or institutions mutually agreed to share resources for some specific mutual beneficial project. For university's long-term sustainability and growth, strategic alliances and partnerships are key factors (Beelen and De Wit, 2012). Internationalization needs a suitable and operational, strategic alliance since this is a driving rationale and an instrument of internationalization. Strategic alliance may be for academic, economic, political or social/cultural purpose. To increase the international mobility of students and academics exchange, and to improve the collaborative research, universities are in need to increase a network of contacts and alliances regionally and internationally (Beamish and Berdow, 2003). Qatar University which ranked as a most internationalized university (THE, 2016), has mentioned in their strategic plan of 2013-2016 that QU will expand national and international partnership to leverage resources (QU, 2013).

Universities can develop strategic alliances by linking participating campuses, governments, and business partners into strategic alliances. One view offered by Hague (1991), illustrates that universities must develop partnerships to survive the onslaught of competition. The partnership is not limited to universities; it may also develop institutional networks and strategic alliances with major companies in fields i.e. publishing communications, and telecommunications. A growing number of corporations are also establishing strategic partnerships with colleges and universities to develop degree programs to meet their specific corporate needs jointly.

\section{Outcomes of Internationalization}

Outcomes of internationalization, in this paper, is divided into three streams; source of revenue, goodwill and reputation and competitive advantage. To reach the supreme objective of becoming a globally recognized institution in the minds of the world, universities are in a struggle to achieve the mentioned outcomes.

\section{$3.1 \quad$ Source of revenue}

It is crucial for HEIs to increase income from international sources so that they can meet the university's financial needs. International students are the reason for the diversity in university's campus life as well as they are the valuable source of revenue for HEIs. For local economies, international students are also a motive to increase the income through expenses on and off campus.

According to Higher Education Statistics Agency (2014), in the period of 2012-13, UK higher education sector derived $12.1 \%$ of total income $£ 3.5$ billion from non-EU students' tuition fees. HEIs are following new ways to generate international income, i.e., international research and collaboration funds, post-graduate funding and consulting and commercial activities (European Commission, 2012).

\subsection{Goodwill and reputation}

Goodwill and reputation is a motivation which encourages universities to achieve a worldwide standing. Internationalization social benefits are; creating businesses and jobs, educating society and stimulating culture. To gain a sustainable reputation in the long run, universities and institutions are in a struggle to attract the brightest scholars and student as well as faculty members, a considerable number of international students, high profile research and training arrangements.

Global university rankings are one of the measuring tool of a university's international reputation and a vital part of the development strategy of an institution and a source of information for transition facilitation to international standards and criteria, and for long-term institutional development (Ablameyko, 2013). Through 
internationalization of higher education, universities and institutes can develop and promote their brand image in the global market. Hence, establishment of overseas sub campus and promote international research collaboration are also key factors for university's long-term reputation.

\subsection{Competitive advantage}

Today, demand for learning is growing rapidly, and access is upgrading, and in response, competition is increasing. Universities are in global competition to bring external resources, talented students and proactive professors and superior in the worldwide ranking. Due to the change of pace in internationalization, education industry has been attributed to increased levels of competition within global markets, as well as the establishment of new technologies which enable more effective control of offshore operations (Cavusgil, 1994; Badrinath, 1994).

HEIs are now more developed in international regarding cooperation and global regarding competition frameworks (Horta, 2009). Research Group Governance (Lectoraat GFA, 2013) conducted research through interviews, and the results show that universities can gain competitive advantage and enhance their overall performance in the local and global competition through internationalization. National and international ranking of universities are a key feature of competition and have become more dominant and challenging in the last five years (Hazelkorn, 2011).

\subsection{Role of internationalization in time higher education world ranking}

In THE World Ranking, internationalization factor has a significant impact in the methodology. The total weight given to internationalization dimension in the THE ranking methodology is $10 \%$; i.e. proportion of international faculty is $5 \%$, and proportion of international students is also $5 \%$ weight (as shown in Table 2).

Table 2: Times higher education ranking's methodology - An overview

\begin{tabular}{|c|c|c|c|}
\hline Criteria & Indicator & Explanation & Weight \\
\hline & Global Academic Peer Review & $\begin{array}{l}\text { Composite score drawn from peer review } \\
\text { survey }\end{array}$ & $40 \%$ \\
\hline Research Quality & Citation Per Faculty & $\begin{array}{l}\text { Score on the base of research performance } \\
\text { factored against the size of the research } \\
\text { body }\end{array}$ & $20 \%$ \\
\hline \multirow{4}{*}{$\begin{array}{l}\text { Teaching Quality } \\
\text { Graduate } \\
\text { Employability } \\
\text { Internationalization }\end{array}$} & Student / Faculty Ratio & Score on the base of student / faculty ratio & $20 \%$ \\
\hline & Global Employee Review & $\begin{array}{l}\text { Score on the base of responses to employer } \\
\text { survey }\end{array}$ & $20 \%$ \\
\hline & International Faculty & $\begin{array}{l}\text { Score on the base of proportion of } \\
\text { international faculty }\end{array}$ & $5 \%$ \\
\hline & International Students & $\begin{array}{l}\text { Score one the base of proportion of } \\
\text { international students }\end{array}$ & $5 \%$ \\
\hline
\end{tabular}

Source: Self-elaboration from http://www.topuniversities.com

\section{Framework to enhance investment in internalization activities}

Internationalization of universities is an investment for the future and involves a long-term commitment to students, staff, and other stakeholders. There are various factors which are influencing investment in the universities through internationalization. Based on prior literature, this study has proposed four main criteria that demand investment in higher education to enhance internationalization. The criteria are internationalization at home, international students and faculty members, expanding ventures and strategic alliances and institutional networks. This study revealed dynamic outcomes through investing in internationalization i.e. source of revenue, competitive advantage and goodwill and reputation. Hence, current study has proposed a dynamic framework as shown in figure 1:

\section{Discussion and policy implications}

\subsection{Internationalization at home (IaH)}

Internationalization at Home ( $\mathrm{IaH})$ is somewhat easier to achieve and require minimal budget since activities are mostly conducted at the university level, with the participation of both local and international students, staff, and guests. 
For formal curriculum, general subjects and issues, such as International Management, International Business, and International Entrepreneurship courses may be introduced. For the university courses, matters that are related to international matters, for instance, cultures of the world and cultural adaptation are to be included.

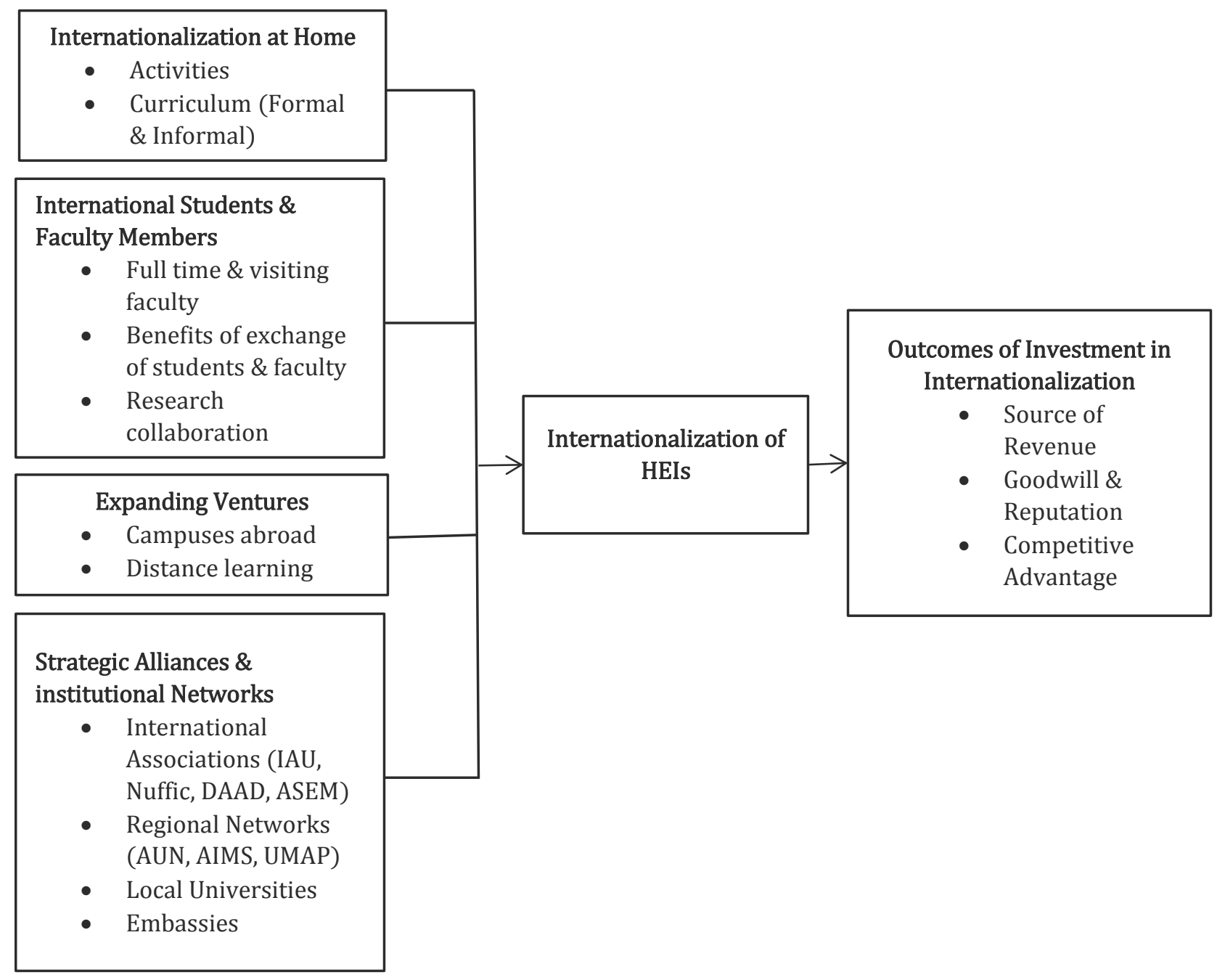

Figure 1: Framework to enhance investment in internalization activities

For informal curriculum, many activities that motivate and involve both local and international students and staff can be conducted. International Week/Day, for an example, is an excellent program to be introduced and internationalized the university's community. Among the activities can be included in the International Week/Day are cultural exhibition, traditional games, international food festival, international drawing competition, international film festival and cultural gala night. In addition, embassies of different countries should be invited and asked to present the education in their countries and inform the opportunities for local and international students to do exchange programs and also to further studies overseas. Inviting embassies to universities is a twopronged strategy, that is, to get information and to do a collaboration between them.

Big-scale international events can also be organized. For example, The University of Jember in Jawa Timur, Indonesia, organized a two-week cultural program and invited international students to participate in the program. The same with the Gadjah Mada University in Yogyakarta, Indonesia that organized International Week and invited international students to participate. Universiti Sains Malaysia in Penang, Malaysia has organized AFLES (ASEAN Future Leadership Summit) since 2013 and APA (Asia Pacific Alliance of Postgraduate Students Association) and invited participants from ASEAN and Asia Pacific countries. These events not only promote the good name of the HEIs but also act as a promotional tool to attract international students to enroll.

\subsection{International students and international faculty members}

Full-time students are paying full tuition fees as per their study tenure. For example; undergraduate students studying for 4 years for bachelor degrees, master students who may finish studies within -3 years and Ph.D. candidates on average 3-4 years, will bring substantial revenue to HEIs. Not only that, international students who 
stay at university's hostel are also a source of income for HEIs. Faculty members that are international and wellknown will attract more local and international students to register at that particular HEIs. The more students enrolled in a university, the more income they bring to the university.

International faculty members can act as catalyst/promoters to the university. For example; Singapore Management University (SMU) promotes its international faculty members with their expertise in order to attract local and international students. To attract more international students to enroll, HEIs should continuously participate in educational promotions and exhibitions. A good suggestion is to involve the existing international students of the HEIs to help during the promotional activities because they will convince and 'influence' the future international students in positive manners. International ALUMNI should also be utilized to continuously taking advantages of word-of-mouth promotion.

\subsection{Expending ventures}

HEIs are expanding ventures through sub-campuses and distance learning. Curtin University and Monash University, Australia have opened their branches in Malaysia. A big budget approach it is but the returns would be impressive in a long run. Curtin University has 11 overseas sub-campuses worldwide. Curtin University Malaysia has the largest number of students (4,411, in 2010, https: //planning.curtin.edu.au) among the subcampuses. Curtin in total has 46,634 students in which 19,876 of them are international students (42.6 \% of a total number of students, https: //planning.curtin.edu.au/stats/student2010.cfm), with Curtin business school has the highest number of students (15,981 students). Universities in Europe are now also following this strategy. For example, the University of Groningen, The Netherlands is opening a branch in China in order to tap the large market in China and Asia in general. Sub-campuses attract not only local students but also international students. In addition, these universities offer pre-University programs such as language studies and foundation studies for international students to fulfill the entry requirement, which generates additional income to these universities.

Another way to attract international students is by offering courses via distance learning /e-learning. The courses can be offered to undergraduates and master's degrees and for Ph.D. level. Working adult students who depend on their jobs as a major source of income would be reluctant to leave their jobs and stay in another country for 3 - 4 years to finish their studies. By offering e-learning programs (e-masters, e-PhD or even e-undergraduate learning programs), international students can take this advantage of continuing their jobs and studies and maintaining their source of income and at the same time not to be separated from their family members. This elearning programs will save international students lots of resources and will attract more international students to enroll in the HEIs.

International faculty members give added values to the students and HEIs alike. They bring in new ideas and new styles of teaching and conducting research which may benefit HEIs in many ways. To attract international faculty members, universities must offer sound remuneration to them. Besides, all perks and benefits must be laid out clearly for them. Cultural adaptation is a major issue that universities must deal with the international faculty members and not forgetting, their families.

\subsection{Strategic alliances and institutional networks}

Firstly, universities should be connected internationally by becoming members to HEIs associations such as International Association of Universities (IAU, based in France), Nuffic (The Netherlands), Deutscher Akademischer Austausch Dienst (DAAD, Germany), Asia-Europe Meeting (ASEM), and Erasmus Mundus+, just to name a few. These associations are important to set connections and to get to know the latest updates on internationalization. Usually, there are seminars and conferences conducted by these associations. Sometimes, they even offer scholarships for students to apply. For example, DAAD is offering scholarships for international students to grab at master's and Ph.D. levels.

Secondly, regional networking is important for universities to collaborate in a closer geographical location. In ASEAN (The Association of Southeast Asian Nations), AUN (ASEAN University Network) and AIMS (ASEAN International Mobility for Students), both headquartered in Bangkok, Thailand offer many international activities such as student and staff exchange. UMAP (University Mobility in Asia and the Pacific) is on a larger geographical scale in which universities in the Asia Pacific region are invited to become members.

Thirdly, networking with the other universities in the home country is a way to ensure that universities are not left behind. This is true on the topic of internationalization, and International Office among universities should get together and work hand in hand in order to realize the internationalization achievement. Example, in Malaysia, there is an association for the directors of International Office of the public universities. The members meet on 
regular basis with an aim to discuss issues and to share experiences and best practices and to learn from each other. This kind of association contributes in settling national level issues such as students' visa, student exchange programs, international students' activities and so forth.

Fourthly, embassies of different countries located in home country should be invited to functions and activities conducted by HEIs. For instance, during the International Week, representatives from various embassies are requested to share information and knowledge about education in their countries and opportunities for local students to further their studies in respective countries. Embassies can help to connect local universities with the universities in their countries of origin. Collaboration between universities of the home and host countries can be developed through this connection which may benefit regarding internationalization to both home and host universities.

\section{Conclusion}

The discussions led us to draw conclusions about the effect of dimensions of internationalization of HEIs which may give ideas for future research. Internationalization is nowadays, a dominant issue for HEIs worldwide with its challenges and opportunities. The study describes practical dimensions which have an influence on the internationalization process and develops a link between HEIs practices and outcomes of internationalization. HEIs can invest in internationalization to generate more revenue, goodwill and reputation in the long run and a competitive edge in the global market. The practical suggestions and practices on HEIs internationalization hopefully may benefit and speed up the process of internationalization of HEIs in the short and long run.

The present study is not without limitations. The one limitation of the study is the higher education industry and there may be variance in results for the research conducted in other industries. The study is also limited to the secondary research data based on research publications and reports. Future research can be conducted on the empirical investigation for the investment in internationalization activities.

\section{References}

AACSB. (2011). Globalization of management education: Changing international structures, adaptive strategies, and the impact of institutions. Bingley, UK: Emerald

Ablameyko, S., Zhuravkov, M., Samakhval V., Polonnikov, A., (2013). International cooperation in building a worldclass university - The case of Belarusian State University; PRADEC Conference Proceedings Volume 2, Issue 1, August 2013.

Adams, T., Banks, M., \& Olsen, A. (2011). International education in Australia: From aid to trade to internationalization. In R. Bhandari \& P. Blumenthal (Eds), International students and global mobility in higher education: National trends and new directions (pp. 107-128). New York: Palgrave Macmillan.

Akhmat, G., Zaman, K., Shukui, T., Ahmed, T. (2013). Educational reforms and internationalization of universities: evidence from major regions of the world: Scientometrics. Published online: 26 September 2013. Hungary 2013.

Altbach, Philip G. (2002), "Knowledge and Education as International Commodities: The Collapse of the Common Good." International Higher Education 28. 2-5.

Altbach, P. G., Knight, J. (2007). The internationalization of higher education: Motivations and realities. Journal of Studies in International Education.

Association of International Educators (NAFSA), 2010, The Economic Benefits of International Education to the United States for the 2009-2010 Academic Year. A statistical analysis. Available at: http://www.nafsa.org/_/File/_/eis2010/usa.pdf.

Badrinath, R. (1994), "Helping small and medium-sized firms to enter export markets", International Trade Forum, Vol. 2, pp. 4-29.

Ball, S. J. (2012). Performativity, commodification and commitment: An I-spy guide to the neoliberal university. British Journal of Educational Studies, 60(1), 17-28

Beamish, J., Berdow, I. (2003): Learning from IJVs: The unintended outcome, Long Range Planning 36(3).

Beelen, J. and de Witt, H. (2012). Internationalisation revisited: New dimensions in the internationalisation of higher education. Amsterdam: Centre for Applied Research on Economics and Management.

Beelen, J., and Jones, E. (2015). Redefining internationalisation at home. In A. Curai, L. Matei, R.

Bhandari, R., \& Chow, P. (2009). Open doors 2009: Report on international educational exchange. New York, NY: IIE

Cavusgil, S.T. (1994), “A quiet revolution in Australian exporters”, Marketing News, Vol. 28 No. 11, p. 18.

Calzolari, P. U. (2010). The future of universities in the bologna process. Honorary doctorate speech. June 4. Isparta, Turkey: Süleyman Demirel University. 
Cattaneo, M., Meoli, M., \& Paleari, S. (2016). Why do universities internationalize? Organizational reputation and legitimacy University Evolution, Entrepreneurial Activity and Regional Competitiveness (pp. 327-346): Springer.

Daniels, J. (2013). "Internationalisation, Higher Education and Educators' Perceptions of Their Practices." Teaching in Higher Education 18 (3).

Ergüder, Ü. (2010). Institutional autonomy: a synopsis of recent studies on higher education reform in Turkey. Presentation at the international conference on institutional autonomy and academic freedom in the era of socio-economic change and transformation. February 18. Isparta, Turkey: Süleyman Demirel University.

European University Association, 2015. Brussels, Belgium. http://www.eua.be

Gürüz K 2008 Higher education and international student mobility in the global knowledge economy State University of New York Press, Albany NY

De Wit, H \& Jones, Elspeth. (2014). We need to change the language of internationalisation. University World News, 16 November 2014, Issue No. 0343.

De Wit, H. (2015). Is the international university the future for higher education? International Higher Education, 80,7

Douglass, J. A., \& Edelstein, R. (2010). The global market for international students: American perspective. http://www.bc.edu/research/cihe/ihe/issues/2010.html

Harris, S. (2008): Internationalising the university, Educational Philosophy and Theory, 40, 2, 346-357.

Hawawini G., The Internationalization of Higher Education Institutions: A Critical Review and a Radical Proposal, INSEAD Working Paper, 2011/12/FIN.

Healey, N. (2015). Managing international branch campuses: what do we know? Higher Education Quarterly, 69(4), 386-409.

H. Horta, (2009). Global and national prominent universities: internationalization, competitiveness and the role of the State, Higher Education, 58 (3) (2009), pp. 387-405.

Hudson, R. (2016). Dominated by economics? Evidence of changing drivers of internationalization and its funding within higher education institutions in Europe. Higher Education Policy, 29(1), 1-19.

Kemp, N. (2016). The International Education Market: Some Emerging Trends. International Higher Education(85), 13-15.

Killick, D. (2007): World-wide horizons: cross-cultural capability and global perspectives -guidelines for curriculum review, in Jones, E./Brown, S. (ed.): Internationalising Higher Education, Abingdon: Routledge.

Knight, J. \& De Wit, H. (1995) Strategies for Internationalization of Higher Education: historical and conceptual perspectives, in H. De Wit (Ed.) Strategies for Internationalization of Higher Education: a comparative study of Australia, Canada, Europe and the United States of America, pp. 5-33. Amsterdam: European Association for International Education.

Knight, J. (2003). Updated definition of internationalization. In International Higher Education. The Boston College Center for International High Education. No. 33 Fall 2-3.

Knight, J. (2004). Internationalization remodeled: Definition, approaches, and rationales. Journal of Studies in International Education 8: 5-31.

Knight, J. (2006). Internationalization: Concepts, complexities and challenges. In J. J. F. Forest \& P. G. Altbach (Eds), International handbook of higher education (pp. 207-228). Dordrecht, the Netherlands: Springer.

Knight, J. (2008). Higher Education in Turmoil: The Changing World of Internationalization. Sense Pub: The Netherlands.

Knight, J. (2014). What is an international university? In OECD (Ed.), The state of higher education 2014. Paris: OECD.

Leask, Betty. 2009. "Using Formal and Informal Curricula to Improve Interactions between Home and International Students." Journal of Studies in International Education, 13 (2): 205-221.

Minola, T., Donina, D., \& Meoli, M. (2016). Students climbing the entrepreneurial ladder: Does university internationalization pay off? Small Business Economics, 47(3), 565-587.

Mohsin, A., \& Zaman, K. (2014). Internationalization of universities: Emerging trends, challenges and opportunities. Journal of Economic Info, 3(1), 1-21.

Nuffic, (2014). Internationalisation at home: Dutch institutional policies.

Organisation for Economic Co-Operation and Development. (2004). Internationalization and trade of higher education: Challenges and opportunities. Paris, France.

Ortiz, A., Chang, L., \& Fang, Y. (2015). International student mobility trends 2015: An economic perspective (WENR. N. P. 2015).

Peters, M. (2002). Education policy research and the global knowledge economy. Educational Philosophy and Theory, 34 (1), 91-102.

Qatar University (2013), Strategic Plan 2013-2016. file:///C:/Users/786/Downloads/QU_Strategic_Plan_20132016_ENG.pdf.pdf 
Rosenzweig MR: Higher education and international migration in Asia: Brain circulation. Paper presented at Annual World Bank Conference on Development Economics (ABCDE)-Regional 2008. Higher Education and Development, Beijing; 2008.

Scott, R. A. (1992) Campus Developments in Response to the Challenges of Internationalization: the case of Ramapo College of New Jersey (USA). Springfield: CBIS Federal.

Solimano A ed 2008 The international mobility of talent Oxford UP, Oxford

Stier, J. (2004). Taking a critical stance toward internationalization ideologies in higher education: Idealism, instrumentalism and educationalism. Globalisation, Societies and Education 2, no. 1: 83-97.

Suter B, Jandl M: Comparative study on policies towards foreign graduates: Study on admission and retention policies towards foreign students in industrialized countries. International Center for Migration Policy Development (ICMPD), Vienna; 2006.

UNESCO institute for Statistics, 2014. http://www.uis.unesco.org/Education/Pages/international-student-flowviz.aspx\#sthash.iLT0G6dn.dpuf

Wächter, B. (2003). An introduction: Internationalisation at home in context. Journal of Studies in International Education 7, no. 1: 5-11.

Warner, G. (1992) Internationalization Models and the Role of the University, International Education Magazine, 1992 , p. 21.

Wildavsky, B. (2010), The Great Brain Race: How Global Universities are Reshaping the World, Princeton University Press, New Jersey, NJ

Wilson, L. (2013). The internationalisation of higher education and research: European policies and institutional strategies. Amsterdam, The Netherlands: European Association for International Education.

Williams A and Balaz M, 2009 International migration and knowledge Routledge, London 